\title{
Promising Educational Technologies for Professional Training
}

\section{Tecnologías educativas prometedoras para la formación profesional}

\section{Marina Georgiyevna Sergeeva*}

Federal State Institution "Research Institute of the Federal Penitentiary Service of Russia", Moscow, Russia.

ORCID: https://orcid.org/0000-0001-8365-6088

\section{Galina Nikolayevna Yulina}

K.G. Razumovsky Moscow State University of Technologies and Management (the First

Cossack University), Moscow, Russia.

ORCID: https://orcid.org/0000-0003-1920-4786

\section{Dmitry Vladimirovich Lukashenko}

Federal State Institution "Research Institute of the Federal Penitentiary Service of Russia", Moscow, Russia.

ORCID: https://orcid.org/0000-0002-0045-6062

\section{Liudmila Alekseevna Egorova}

Peoples' Friendship University of Russia (RUDN University), Moscow, Russia.

ORCID: https://orcid.org/0000-0002-5159-1512

\section{Pavel Rustamovich Bazarov}

Federal State Institution "Research Institute of the Federal Penitentiary Service of Russia", Moscow, Russia.

ORCID: https://orcid.org/0000-0002-6295-3646

Received 02-12-20 Revised 03-13-20 Accepted 07-13-20 On line 08-29-20

*Correspondence

Email: sergeeva198262@mail.ru
Cite as:

\footnotetext{
Sergeeva, M.G., Yulina, G. N., Lukashenko, D. V., Egorova, L A., \& Bazarov P.R. (2020). Promising Educational Technologies for Professional Training. Propósitos y Representaciones, 8 (SPE2), e691. Doi: http://dx.doi.org/10.20511/pyr2020.v8nSPE2.691
} 


\section{Summary}

Comprehensive changes in Russian education are aimed at meeting the requirements of the modern economy and society. At the same time, the main vector in this area is the coordination of the content and component composition of professional training with the demands of the labor market and with the urgent need to increase the availability of high-quality educational services. Public experience demonstrates that objective reality makes significant adjustments to the professional training and education. Therefore, teachers should acknowledge and reflect in their professional activities all the new requirements presented by society in a timely manner. In the context of professional education, intensive search is carried out for adequate forms and methods to improve the effectiveness of education. In this regard, the practical value of simulation methods and technologies, aimed at revealing the creative potential of a future specialist, their individual and professional properties and the ability to function successfully in the new economic conditions, is increasing. Educational technologies as mechanisms for the joint activity of the teacher and students are aimed at the development of certain skills and abilities, as well as personal and professional development. The teacher should correctly apply educational technologies and methods to provide quality training for competent professionals. The variety of these methods is proposed to encourage intrinsic motivation, a lively interest of students in learning and self-development. The competencies of a qualified specialist and the criteria that he/she must meet have become the basis for creating a generalized concept of a professional. Along with the individual properties of the student, the foundation of the concept is knowledge and skills in the areas provided by the general and special components of the Federal State Educational Standards. In the framework of professional education, the main place in the educational process should be occupied by active educational technologies and methods, focused on intensifying the cognitive activities of students, supporting creative initiative and abilities and development of intellectual needs.

Keywords: Quality of Training; Educational Technology; Training Method; Future Specialist; Simulation Method.

\section{Resumen}

Los cambios integrales en la educación rusa tienen como objetivo cumplir con los requisitos de la economía y la sociedad modernas. Al mismo tiempo, el vector principal en esta área es la coordinación del contenido y la composición de componentes de la formación profesional con las demandas del mercado laboral y con la urgente necesidad de aumentar la disponibilidad de servicios educativos de alta calidad. La experiencia pública demuestra que la realidad objetiva hace ajustes significativos en la capacitación y educación profesional. Por lo tanto, los maestros deben reconocer y reflejar en sus actividades profesionales todos los nuevos requisitos presentados por la sociedad de manera oportuna. En el contexto de la educación profesional, se realiza una búsqueda intensiva de formas y métodos adecuados para mejorar la efectividad de la educación. A este respecto, el valor práctico de los métodos y tecnologías de simulación, destinados a revelar el potencial creativo de un futuro especialista, sus propiedades individuales y profesionales y la capacidad de funcionar con éxito en las nuevas condiciones económicas, está aumentando. Las tecnologías educativas como mecanismos para la actividad conjunta del profesor y los estudiantes están dirigidas al desarrollo de ciertas habilidades y destrezas, así como al desarrollo personal y profesional. El profesor debe aplicar correctamente las tecnologías y métodos educativos para proporcionar una formación de calidad a profesionales competentes. Se propone la variedad de estos métodos para fomentar la motivación intrínseca, un interés vivo de los estudiantes en el aprendizaje y el autodesarrollo. Las competencias de un especialista calificado y los criterios que debe cumplir se han convertido en la base para crear un concepto generalizado de profesional. Junto con las propiedades individuales del estudiante, la base del concepto es el conocimiento y las habilidades en las áreas proporcionadas por los componentes generales y especiales de los Estándares Educativos del Estado Federal. En el marco de la 
educación profesional, el lugar principal en el proceso educativo debe estar ocupado por tecnologías y métodos educativos activos, enfocados en intensificar las actividades cognitivas de los estudiantes, apoyando la iniciativa creativa y las habilidades y el desarrollo de las necesidades intelectuales.

Palabras clave: Calidad de la formación; Tecnología educativa; Método de formación; Futuro especialista; Método de simulación.

\section{Introduction}

To meet the requirements of the labor market, being in the conditions of fierce competition, professional educational organizations should pay great attention to the quality of training of a future specialist. In the Russian Encyclopedia of Professional Education, quality is positioned as a set of signs, characteristics of goods, services, activities, etc., allowing citizens to satisfy their needs, follow their vocation and fulfill the obligations indicated in contracts, standards and other documents, as well as presented by society in non-written form (Batysheva, 1998). In a practiceoriented context, the following types of quality are distinguished: the quality of goods, services, materials, labor, work, products (Sharonova, 2003; 2005). Russian economist Prof. A. Romanov describes quality as an integral feature that contains a complex expression of a large number of factors, including the current stage of development of the economy, the ability to build and manage the process of creating quality products in any organizational unit (Romanov, 1995).

At the same time, based on the world experience, it can be stated that a market economy is unthinkable without competition. In a competitive environment, criteria of quality become an indicator of the effectiveness and financial well-being of the enterprise.

Such a concept as the "quality of knowledge" implies the comparison of types of knowledge (theories, concepts, principles, laws, practical experience, information about methods of activity, evaluative and other data) with the content of education. The quality of knowledge is characterized by a number of key properties:

- completeness (the amount of knowledge about the analyzed objects and phenomena);

- fundamentality (a combination of meaningful connections between different types of knowledge);

- consistency (understanding the position of a certain knowledge in a scientific concept, methods of practical use);

- efficiency (the ability to apply available information in different educational and professional circumstances);

- mobility (the ability to determine the main and alternative ways of using information in specific, non-standard situations);

- specificity (the ability to differentiate knowledge and use information in specific educational and professional circumstances);

- generalization (the ability to represent knowledge in a generalized, conceptual form); knowledge);

- awareness (a clear idea of how to acquire important information, the ability to gain

- sustainability (stable retention in memory of useful knowledge and mechanisms of their use) (Shmeleva, 2000).

The most important role in professional education is played by mobility, efficiency and awareness, since they make a fundamental contribution to the training of competent specialists. 
The leading role in professional education belongs to such characteristics of the quality of knowledge as efficiency and flexibility, since the development of professional skills of competitive specialists depends on them (Sharonova et al., 2018).

In the market of educational services, modernization and updating is taking place, requiring professional educational organizations to update the requirements for the training of specialists. In such a situation, a correlation is needed between the content of education and advanced technologies of professional training. Educational institutions should make an informed choice of innovative methods, forms, techniques, training technologies, focused on the learning outcomes for a changing labor market (Sharonova, Avdeeva, 2019).

\section{Literature review}

At the beginning of the $21^{\text {st }}$ century, the Russian education market entered a stage of intensive development, which stimulated educational institutions to look for new approaches to teaching and learning. A special place is occupied by content and technological aspects. To meet constantly changing requirements, schools and universities are forced to create and implement the most effective methods, technologies, forms of organization of the pedagogical process.

Active development and practical implementation of educational technologies started in 1960-70s in Europe and the United States and is associated primarily with the works of B. Bloom (1956). Researchers F. Percival and G. Ellington pointed out that the term "technology" in education covers any possible means of presenting information, including technical equipment, such as television, radio, various means of images projection and other audio-visual resources (Percival, Ellington, 1984).

Many researchers distinguish four dimensions of scientific understanding and the use of term "educational technology". These profiles include:

- educational technology as an instrument, i.e. production and application of methodical tools, educational equipment and technical means of training for the educational process (Gray, Herr, 2000; Sakamoto, 1974; Spaulding, 1978; Ju et al., 2017);

- educational technology as a method, i.e. the process of communication (strategy, model, technique to perform educational tasks), based on a certain algorithm, program, system of the interaction of pedagogical process participants (Silber, 1972; Wang et al., 2017);

- educational technology as a research sphere, considered as a vast area of knowledge based on the social and natural sciences (Gray, Herr, 2000; Seyfried, Kohlmeyer, Furth-Riedesser, 2000);

- educational technology as a complex multidimensional process (Hug, 1985; Mitchell, 1978).

American educator and researcher James D. Finn noted that "only unsophisticated people believe that educational technology is just a set of hardware, equipment and teaching aids. Technology means much more than that. It is a way of organizing education, a way of thinking concerning training content, people, institutions, model, and man-machine systems" (Denisova, 2000).

Based on the analysis of more than a hundred sources, related to the definition under study, P.D. Mitchell described the educational technology as "an area of study and practice (within education) concerned with all aspects of the organization or educational systems and procedures whereby resources are allocated to specified and potentially replicable educational outcomes" (Mitchell, 1978). 
UNESCO experts consider educational technologies in a broader sense, as a systematic approach to organizing, using and diagnosing the effectiveness of the entire process of mastering and facilitating learning. Speaking about the technology of pedagogical activity, a classic of Soviet education A.S. Makarenko emphasized the gap between the theoretical preparedness of teachers and the level of their practical skills (Semushina, Yaroshenko, 2001).

Today, about 2,000 business-oriented games (business games, business simulations) are used in the educational process (Sharonova, Trubnikova, Sokolova, 2018). Their design with experimental goals began to develop actively in the middle of the 20th century. The earliest samples appeared in the USA, and soon business games quickly became popular in a number of other countries (Canada, Great Britain, Germany, France, the Soviet Union). In the 1960s, Russian developers created two high-quality business games, Reforma and Astra. Research centers have appeared all over the world that deal with the theoretical and practical aspects of such activities, and research and educational events have been regularly held to promote active learning methods. Recently, the "golden age" of business games has come.

In connection with the transition of Russia to the market economy, it became necessary to model future professional activities during the period of higher education. Business games came to the rescue, helping to model the professional activity of a specialist in conditions close to the real production process, acting as a means and method of training and adaptation to future professional activities and interactions (Yurieva, 2003).

\section{Proposed Methodology}

In the modern world we observe a very rapid obsolescence of knowledge that needs to be updated and improved through self-education. A modern teacher should teach students to study throughout their lives. For this, students need to learn to think independently, analyze information, have their own point of view when solving a problem, and be prepared to synthesize the required information for effective work. Active teaching and learning methods are aimed at developing the personal qualities of students, directly related to the changing role of education - the cognitive abilities, creative thinking, readiness to self-education, professional development, the ability to work with information (Sharonova et al., 2018).

Active teaching and learning methods are applied at different stages of professional training: in the initial mastery of knowledge, in the consolidation and improvement of knowledge, in the development of skills. In fact, there is no clear border between active and passive (productive and reproductive) methods, but by combining various methods, the teacher can achieve the main result - to increase the student's cognitive activity. Depending on the focus on the formation of a knowledge system or mastery of skills, active teaching and learning methods are divided into non-simulation and simulation (Table 1). 
Table 1.

Classification of Active Methods

\section{Non-simulation methods}

Simulation methods
Non-playable methods

Play-based methods

\section{Problem lecture}

Heuristic discussion

Training discussion

Search lab work

Research method

Independent work with the training

(programmed learning )

Independent work with the textbook

Analysis of professional situations

The decision of situational problems

Exercises - instructions

Performing individual tasks

(practice)

Case study

Computer simulation

Role playing

Organizational - activity

games

Moderation

Analysis of pedagogical research works on the use of simulation methods revealed their advantages and disadvantages, identifying their characteristic features in the training of a practiceoriented specialist and evaluating the effectiveness of their use in conducting classes with students of professional educational organizations (Sergeeva, 2007; Sharonova, 2004a; 2004b; Konstantinovskii et al., 2004).

\section{Result analysis}

Simulation methods are classified into non-playable and play-based.

The method of discussing professional situations. The students are offered a specific professional situation with a description of the initial conditions and behavior of the workers involved in it. It is necessary to consider their actions and give them an objective assessment. Tasks for understanding the presented situations are carried out individually or in groups of 3 to 5 students, after which the participants share the conclusions they came to and organize a discussion.

Performing situational tasks related to production contributes to the development of professional skills. A key didactic resource is a situational task consisting of basic conditions (a description of the situation and initial quantitative information) and a question (task) formulated for the participants. The task should contain the information necessary for its correct implementation, or conditions implicitly containing these data (i.e., allowing to extract them). It is necessary that the tasks fully meet the professional content and the qualification level of the students or insignificantly exceed them in complexity. The lesson using the described method is aimed at acquiring the skills to apply the theoretical knowledge to eliminate specific managerial difficulties. Consequently, during the lesson, the acquired theoretical knowledge is structured, the 
skills to discuss various issues are improved. Thus, we develop two opposite and at the same time interconnected abilities, to manage and execute other people's orders.

In carrying out exercises involving a pattern (instructions), the student must come to an independent conclusion about the characteristics of various substances (subjects, phenomena), the relationship between them and the methods for determining these characteristics. Students summarize the data obtained on the basis of experiments and observations, and draw certain conclusions. This additionally argues the derived theoretical principles, makes them more reliable.

When working with personality-oriented tasks within the framework of practical training, students increase their level of competence in the future. This type of practice represents the first stage of applied practice-oriented education, a mandatory component of the training of qualified personnel in the modern economy. Such training not only provides the student with the skills and abilities necessary for the future profession, but also helps to consolidate theoretical information.

The case study method (case study) uses a set of detailed descriptions of various situations, and takes into account potential solutions to existing problems. Students find and characterize certain steps to eliminate the difficulties encountered with listing the strengths and weaknesses of each idea, so that in the end they can vote for the option that is most suitable for the person (case character).

Simulation of professional activity by means of computer simulators helps to develop skills - operations performed automatically due to a significant number of repetitions.

In the context of role-playing, the most significant place is given to the specific task that unites all participants. Trying to fulfill it, the students play the roles, assuming different goals and needs. Despite the given differences, students are supposed to come to a compromise, a solution that suits everyone (albeit not causing general enthusiasm).

The business game contributes to the revealing of the creative potential of young people, makes them more independent and active. This genre became especially popular at the beginning of the $21^{\text {st }}$ century, which was due to a change in economic paradigms and the need for an informal approach to training specialists related to it. In the process of a business game, an undesired, typical, and ideal behavior of a "student" or "employee" is designed in purposefully built situations - pedagogical or professional. A business game is both an instrument and a way of preparing and adapting to a future reality: production responsibilities and social interaction almost inseparable from them.

The effectiveness of game-based simulation training methods (simulating activities on the simulator; role-playing, business game, moderation) is presented in Table 2. 
Table 2.

Efficiency of using simulation methods in professional training

\begin{tabular}{|c|c|c|}
\hline № & Method & Characteristics \\
\hline 1. & $\begin{array}{l}\text { Simulation of } \\
\text { professional activity by } \\
\text { means of simulators }\end{array}$ & $\begin{array}{l}\text { It forms skills - actions that, as a result of repeated } \\
\text { repetitions, become automatic. }\end{array}$ \\
\hline 2. & Role playing & $\begin{array}{l}\text { For role-playing, it is especially important to pose one } \\
\text { specific problem to the players. Solving it, participants } \\
\text { fulfill roles characterized by various interests; in the } \\
\text { process of their interaction a compromise solution must be } \\
\text { found. }\end{array}$ \\
\hline 3. & Business game & $\begin{array}{l}\text { Promotes the development of creative abilities of future } \\
\text { specialists, their individuality and independence. } \\
\text { Especially widely business games began to be used in } \\
\text { recent years. The transition to the market economy, the } \\
\text { need for an informal system of training have become an } \\
\text { incentive for the widespread use of game modeling in the } \\
\text { educational process. The business game can be considered } \\
\text { as "modeling" the real activities of a "specialist" in various } \\
\text { purposefully created pedagogical or production situations. } \\
\text { The business game acts as a means and method of } \\
\text { preparing and adapting to work and social contacts. }\end{array}$ \\
\hline 4. & Moderation & $\begin{array}{l}\text { Moderation is the process of establishing rules and } \\
\text { monitoring their implementation when working with the } \\
\text { audience. Moderation is a mode of holding a meeting that } \\
\text { leads to results faster and enables all participants to make } \\
\text { common decisions. }\end{array}$ \\
\hline
\end{tabular}

As an example of moderation, we discuss the problem "What qualities a modern teacher should have". Students need to name 7 qualities from the position of administration, parents, students, teachers. Of the participants, four corresponding groups are formed, which in the course of discussions define the qualities of the teacher from the point of view of their group (Table 3 ). 


\section{Table 3.}

The qualities of a modern teacher

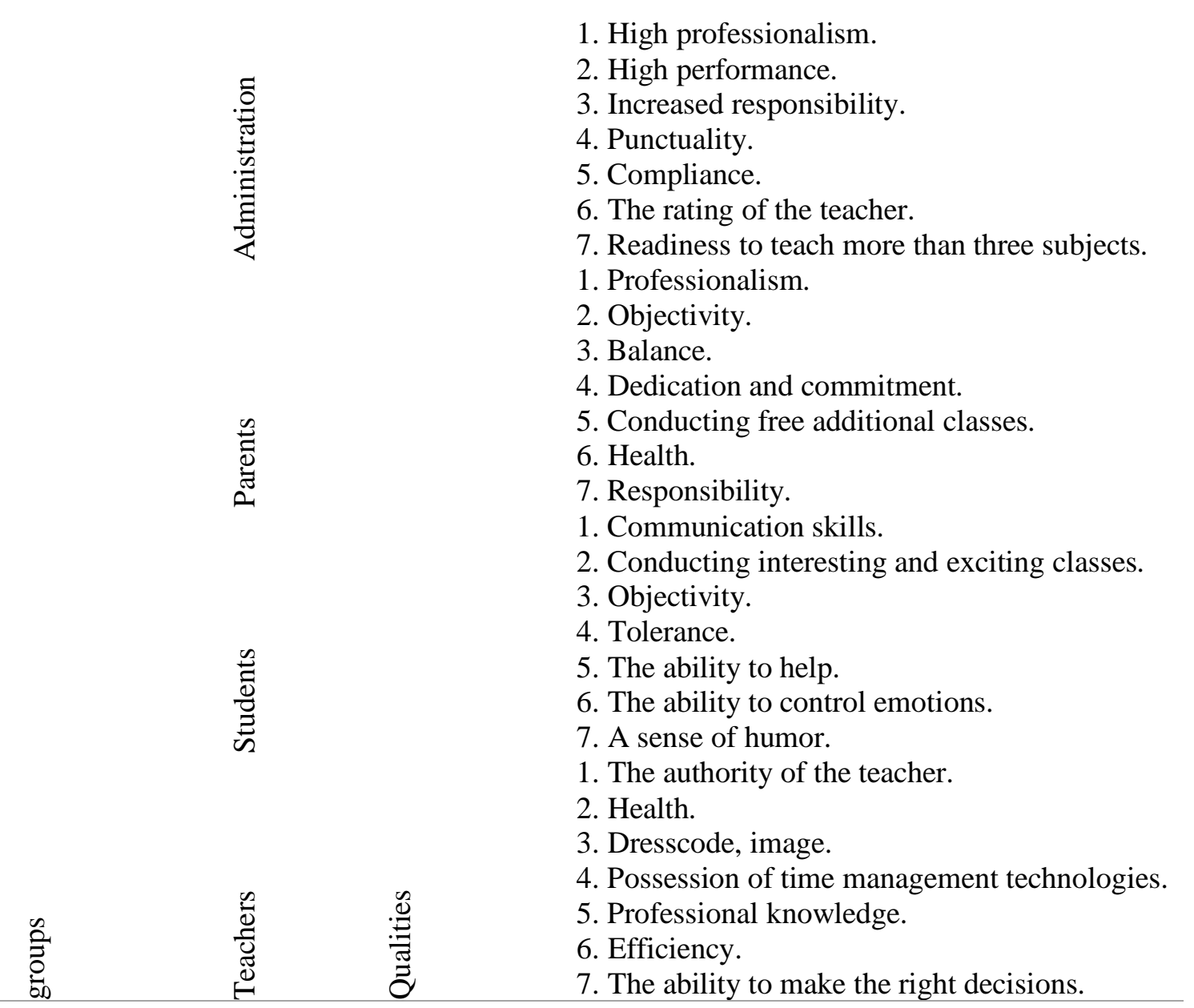

At the next stage, four qualities, the same or prevailing in all groups, were identified. After discussion in small groups and in plenary discussion, participants distinguished professionalism, emotional balance, image, objectivity.

According to the selected qualities, the following areas of discussion and solution of the problem were highlighted: why this quality is necessary, why this quality is underdeveloped and how it could be developed, what difficulties can arise in the process of development.

As a result of moderation, a list of measures for the development of the indicated qualities of the teacher was compiled.

Tables 4 and 5 show which personal characteristics and aspects of professional knowledge could be developed and improved using specific imitation training methods identified in the research process of Prof. M.G. Sergeeva (2007). 
Table 4.

Development of personal characteristics using simulation methods

\begin{tabular}{|c|c|c|c|c|c|c|c|}
\hline Teaching methods & 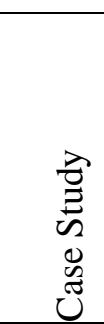 & 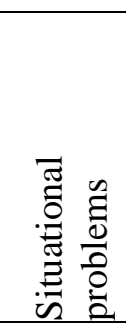 & 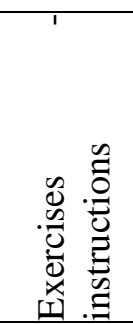 & 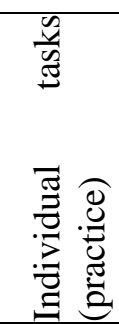 & 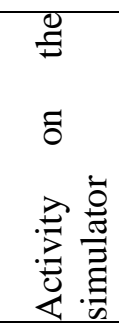 & $\begin{array}{l}\stackrel{0}{0} \\
\frac{\pi}{2} \\
\frac{0}{2} \\
\frac{0}{0}\end{array}$ & 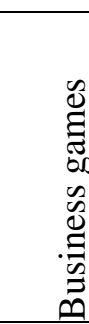 \\
\hline Empathy & + & + & - & - & - & + & + \\
\hline Authenticity & + & + & - & $+!$ & - & $+!$ & $+!$ \\
\hline Stress management & + & + & - & + & $+!$ & $+!$ & $+!$ \\
\hline Perception level & + & + & + & $+!$ & + & $+!$ & $+!$ \\
\hline Intuition level & + & + & - & $+!$ & $+!$ & $+!$ & $+!$ \\
\hline Analytical abilities & + & + & - & $+!$ & - & $+!$ & $+!$ \\
\hline Quick thinking & - & - & + & - & $+!$ & $+!$ & $+!$ \\
\hline Observational skills & + & + & - & + & + & + & $+!$ \\
\hline $\begin{array}{l}\text { Critical and integral } \\
\text { thinking }\end{array}$ & + & + & - & + & - & + & + \\
\hline Combination skills & + & + & - & + & - & $+!$ & $+!$ \\
\hline Ability to take risks & + & + & - & - & - & $+!$ & $+!$ \\
\hline Responsibility & + & + & - & $+!$ & - & + & + \\
\hline $\begin{array}{l}\text { Ability to lead and } \\
\text { obey }\end{array}$ & + & + & - & - & - & $+!$ & $+!$ \\
\hline
\end{tabular}

Note:

+- the method develops a personal characteristic;

- - the method does not develop a personal characteristic;

+ ! - the method better than others contributes to the development of personal characteristics.

Table 5.

Developments of professional knowledge by simulation teaching methods

\begin{tabular}{|c|c|c|c|c|c|c|c|}
\hline $\begin{array}{l}\text { Methods } \\
\text { Core professional } \\
\text { characteristics } \\
\text { of knowledge } \\
\text { quality }\end{array}$ & 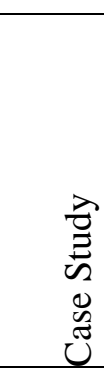 & 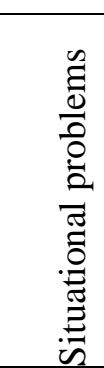 & 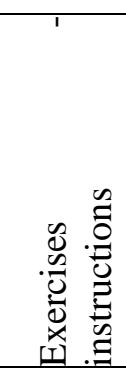 & 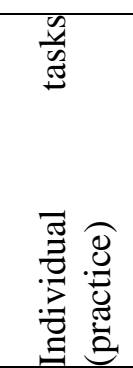 & 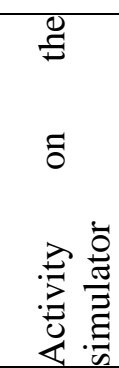 & 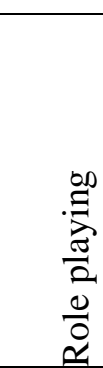 & 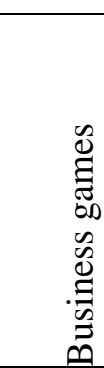 \\
\hline Completeness & + & + & + & + & + & + & + \\
\hline Depth & $+!$ & + & + & + & + & $+!$ & $+!$ \\
\hline Consistency & - & - & + & $+!$ & - & + & + \\
\hline $\begin{array}{l}\text { Systematic } \\
\text { approach }\end{array}$ & - & - & + & $+!$ & - & + & + \\
\hline Expediency & $+!$ & + & $+!$ & + & $+!$ & $+!$ & $+!$ \\
\hline Flexibility & + & + & - & + & - & $+!$ & $+!$ \\
\hline Specificity & + & $+!$ & + & $+!$ & $+!$ & $+!$ & $+!$ \\
\hline Generalization & + & + & + & $+!$ & + & + & $+!$ \\
\hline
\end{tabular}

Note:

+ - the method develops knowledge quality;

- - the method does not develop knowledge quality;

$+!-$ the method better than others contributes to the development of knowledge quality. 
Comparative analysis of the simulation training methods allows us to state that none of the proposed methods works in isolation, but a complex of simulation methods is needed, which allows to create professional and personal qualities of a future specialist. This allowed Prof. M.G. Sergeeva to develop simulation method of professional training "Educational Firm" as a systematic complex of simulation methods (2007).

\section{Conclusion}

Comparative analysis of the simulation methods revealed their advantages and disadvantages. This allowed us to identify the features of the simulation methods of training in the competence model of the graduate.

In the course of the study, two types of characteristics were considered: the quality of professional knowledge (completeness, depth, systematicity, expediency, efficiency and others) and personal (empathy, authenticity, stress tolerance, development of perception and intuition, analytical abilities, speed of reaction, and others).

Tested in the process of research at different educational levels, the method of training "Educational Firm" is considered as a systematic set of simulation methods and has all the features inherent in the methods (certain form and management of cognitive activity of students; specific assimilation of knowledge; management and exchange of cognitive information between students and teachers; stimulation and motivation of educational and cognitive activity; control over the effectiveness of the educational process). This method of training provides opportunities for the teacher:

- in the organization of the educational process - to simulate elements of educational activities in the workplace; to create an imitation of the future professional activity; to combine learning objectives with commercial tasks; to show students in practice interpersonal relationships in market conditions etc.;

- in setting pedagogical learning goals - to reduce significantly the gap between the process of education and the requirements of the labor market; to establish new relationships between students and teachers; to form and develop personal qualities of students in professional, managerial and ethical dimensions; to increase the motivation of students for the chosen specialty; to gain experience in the teamwork, etc.;

- in solving pedagogical problems - to improve the quality of training specialists competitive in the labor market; to improve the ability to adapt to new types and conditions of professional activity; to motivate students to improve professional skills, to instill skills of rapid orientation in the flow of information, etc.

\section{References}

Batysheva, S.Ya. (1998). Encyclopedia of vocational education: in 3 volumes. Moscow: APO.

Bloom, B.C. Krathwohl, D.R. (1956). Taxonomy of educational objectives: Handbook I: The cognitive domain. New York: McKay.

Denisova, T.V. (2000). Innovative teaching methods. Scientific and research and educational and methodological work in secondary vocational schools: Collection of materials. Moscow: Ministry of Education of the Russian Federation scientific and methodological center of secondary vocational education.

Gray, K., Herr, E. (2000). Other ways to win: creating alternatives for high school graduates. Thousand Oaks, California: Corwin Press, Inc. 
Gray, K., Herr, E. (2000). Workforce education: The basics. Needham Heights, MA: Allyn and Bacon.

Hug, W.E. (1985). Educational Technology: Local Center. The International Encyclopedia of Education. Oxford.

Ju, R., Buldakova, N.V., Sorokoumova, S.N., Sergeeva, M.G., Galushkin, A.A., Soloviev, A.A., Kryukova, N.I. (2017). Foresight methods in pedagogical design of university learning environment. Eurasia Journal of Mathematics, Science and Technology Education, 13(8), 5281-5293.

Konstantinovskii, D.L., Sorokina, N.D., Sharonova, S.A., Fedorov, I.V., Toshchenko, Zh.T. (2004). Education as a factor of social differentiation and mobility: (A roundtable). Russian Education and Society, 46(10), 7-30.

Mitchell, P.D. (1978). Educational Technology. The Encyclopedia of Educational Media Communications and Technology, 132-185.

Percival, F., Ellington, H.A. (1984). Handbook of Educational Technology. Leningrad.

Romanov, A.N. (1995). Marketing. Moscow: Banks and Exchanges.

Sakamoto, T. (1974). The Roles of Educational Technology in Curriculum Development. Curriculum Development by Means of Educational Technology. Centre for Educational Research and Innovation, OECD.

Semushina, L.G., Yaroshenko, N.G. (2001). Content and learning technologies in secondary specialized educational institutions: a manual for teachers of secondary vocational education institutions. Moscow: Mastery.

Sergeeva, M.G. (2007). Imitation methods of vocational training: Monograph. Moscow: ITIP RAO.

Seyfried, E., Kohlmeyer, K., Furth-Riedesser, R. (2000). Supporting quality in vocational training through networking. CEDEFOP. Luxembourg: Office for Official Publications of the European Communities.

Sharonova, S. (2003). Game situations in sociology teaching. Sotsiologicheskie Issledovaniya, 2, 130-135.

Sharonova, S., Avdeeva, E. (2019). Transformation of Educational landscape in the Era of Smart Society. 13th International Multi-Conference on Society, Cybernetics and Informatics, Proceedings, 2, 110-115.

Sharonova, S.A. (2004a). Game technologies as manipulative methodology. Sotsiologicheskie Issledovaniya, 1, 98-102.

Sharonova, S.A. (2004b). Regarding interactive methods in teaching sociology course. Sotsiologicheskie Issledovaniya, 12, 130-132.

Sharonova, S.A. (2005). From the history of sociological education abroad. Sotsiologicheskie Issledovaniya, 3, 119-126.

Sharonova, S.A., Trubnikova, N.V., Erokhova, N.S., Nazarova, H.A. (2018). Intellectual colonialism and national education systems. XLinguae, 11(2), 338-351.

Sharonova, S.A., Trubnikova, N.V., Sokolova, N.L. (2018). Interpreting religious symbols as basic component of social value formation. European Journal of Science and Theology, $14(3), 117-127$.

Shmeleva, N.A. (2000). The effectiveness of non-traditional forms of training in secondary vocational education institutions: Authoreferat dis. ... cand. Ped. sciences. Moscow.

Silber, K. (1972). The Field of Educational Technology: A Statement of Definition. Audiovisual Instruction, 8, 18-30.

Spaulding, S.C. (1978). Technological devices in education. The encyclopedia of educational media communications and technology, 41-67.

Wang, S., Gorbunova, N.V., Masalimova, A.R., Bírová, J., Sergeeva, M.G. (2017). Formation of Academic Mobility of Future Foreign Language Teachers by Means of Media Education Technologies. Eurasia Journal of Mathematics, Science and Technology Education, 14(3), 959-976.

Yurieva, E.V. (2003). Simulation training and role-playing game. Specialist, 6, 9 - 10. 